Article

\title{
Gender Inequity: Older Workers and the Gender Labor Income Gap in Peru
}

\author{
Maria Amparo Cruz Saco ${ }^{1,2, *}$, Mirian Gil ${ }^{3}$, and Cynthia Campos ${ }^{4}$ \\ ${ }^{1}$ Economics Department, Connecticut College, USA \\ ${ }^{2}$ CIUP, Universidad del Pacífico, Peru \\ ${ }^{3}$ Economics Department, Universidad Nacional Mayor de San Marcos, Peru \\ ${ }^{4}$ Economics Department, Universidad del Pacífico, Peru \\ * Corresponding author (macru@conncoll.edu)
}

Submitted: 1 August 2021 | Accepted: 31 August 2021 | Published: 25 January 2022

\begin{abstract}
Using annual household surveys from 2004 to 2019, we examine the existence of a gender labor income gap among older persons in Peru. Two labor income models are estimated: Model 1 uses a basic set of demographic, socioeconomic, and personal characteristics as regressors (also called endowments); Model 2 uses the basic set plus additional personal characteristics. The Mincer-type relationship holds with positive returns for education and experience, and the anticipated association to the endowments. The Oaxaca-Blinder decomposition yields an explained labor income gender gap of $44.4 \%$ (Model 1) and 51.5\% (Model 2), i.e., controlling for endowments, approximately one half of the labor income difference remains unexplained and can be attributed to discrimination and labor segregation. In light of these results, we estimate Model 3 with two additional variables (head of household and beneficiary of intergenerational private transfer) which attempt to capture gendered stereotypes. With these two variables which provide information on gender discrimination the explained labor income gap for Model 3 is $71.1 \%$ - an increase of $19.6 \%$. The unexplained component of the difference in labor income amounts to $28.8 \%$ that we attribute to unobserved variables that operate as post-labor market elements in patriarchal societies. Results show that gender inequity during a woman's life-span manifests acutely among older women, which raises important implications for policy interventions.
\end{abstract}

\section{Keywords}

aging; gender inequity; labor earnings; older persons; pension coverage; Peru

Issue

This article is part of the issue "Recent Trends in Inequality and Exclusion in Latin America" edited by Maria Amparo Cruz Saco (Connecticut College / Universidad del Pacífico).

(C) 2022 by the author(s); licensee Cogitatio (Lisbon, Portugal). This article is licensed under a Creative Commons Attribution 4.0 International License (CC BY).

\section{Introduction}

Peru is a patriarchal society with gendered barriers to full labor participation. Gálvez (2001) documents that women take on low-productivity jobs that pay low wages, have lower labor market participation rates, and endure higher unemployment rates. Women perform a disproportionate number of unremunerated hours in domestic and care-giving activities at home (Beltrán \& Lavado, 2014). Beltrán and Lavado (2014, p. 59) show that the unaccounted and invisible domestic work at home (mostly female work) increases the average poverty rate by $12.6 \%$. Lavado (2017) shows that moms who take care of their children and sustain the reproduction of their families have less time for their own educational and/or professional advancement. Women's access to registered employment-that is, formal employment with social security benefits-is much lower than their male counterparts (Ministerio de Trabajo y Promoción del Empleo, 2019). Older women have lower educational achievement in Peru (Instituto Nacional de Estadística e Informática [INEI], 2021b). For younger women with higher educational attainment, discrimination is still an issue: Barrantes and Matos (2019) discuss 
the interplay of structural barriers and gender stereotypes that impede young women from landing a good paying job despite their higher educational attainment. Other scholars have emphasized that gender discrimination and segregation date back to colonial times, extending over the two-century-long republic (Beltrán et al., 2021, pp. 445-447).

Studies document the existence of an overall gender income or wage gap during the active life of workers attributable to inequitable societal structures (Barrantes-Cáceres \& Matos-Trifu, 2019; Beltrán \& Lavado, 2014; Lavado, 2017). However, they do not always capture the nuances of gender income inequity among older persons. This is problematic, because gender inequity cumulates throughout a woman's life and the income gap actually widens over time:

Gender is a significant determinant of well-being in old age. Women face greater challenges in older age than men. Part of this is due to longevity. Women, on average, live five years longer than men, and the global population of older people is significantly skewed toward women. They must maintain their income streams for longer time, and their vulnerability increases with age. They are much less likely to be employed in the formal sector and are therefore less likely to have a pension or formal work later in life. (Center for Financial Inclusion \& HelpAge International, 2015, pp. 4-5)

In addition, the incidence of poverty among older women tends to be high (Huenchuan, 2012, 2013; Stark et al., 2005). For that reason, when examining gender income inequity and possible policy interventions, the effect of age cannot be ignored.

To that end, Beltrán et al. (2021) offer a lifespan approach to the analysis of gender inequity. During adulthood, they estimate the gender income gap, and to capture gender income inequity in old age, they use pension coverage rates as a proxy. The pension scheme in Peru consists of a contributory component with two parallel systems: the private pension system (PPS) and the national pension system (NPS). A non-contributory or social pension called Pensión 65 (P65) for older persons who are extremely poor supplements the contributory scheme (P65 covers $23 \%$ of persons $65+$ ). The pension coverage rate proxy is useful because inequities in the pension system reflect in part labor segmentation and gender discrimination. Beltrán et al. (2021) use data from INEI (2021b, p. 11) which reports that only one third of older persons-60-year-olds or older $(60+)$-earn a contributory pension. This coverage rate has a severe gender gap: $43.5 \%$ of older men earn a contributory pension compared to $24.9 \%$ of older women.

However, relying on the coverage rate might underestimate or otherwise distort the extent of the old age gender inequity, because it refers to only a subset of the population of older persons. Since pension coverage of older persons is low in Peru (Cruz Saco \& Gil, 2021), and, in general, the pension scheme is inadequate (Cruz Saco et al., 2018a; Olivera \& Clausen, 2014), older persons go to work in large numbers to make ends meet. INEI (2021b, Table 7.1) reports that before the Covid-19 pandemic, in January-March 2020, 55.4\% of older persons were part of the economically active population (EAP). By gender, their participation was $65.7 \%$ for males and $46.2 \%$ for females (as the pandemic unfolded, labor market participation rates dropped for all ages, and for persons $60+$, it dropped to $49.7 \%$ in 2021 ). It is so commonplace for older persons to work that, unlike other countries, Peru does not have a maximum age limit for its EAP statistics (International Labour Organization, 2003).

In this study, we focus exclusively on older persons and use labor income data rather than pension coverage rates. By focusing on labor income of older persons who work, and controlling for having a pension benefit, the measure of gender income inequity will be better estimated. We ask three questions: Are the same institutional patterns and value systems that have perpetuated discrimination against women in the labor force playing out with similar intensity during old age? If so, how? What lessons can we draw to inform policy interventions to eliminate gender inequity for all ages but more specifically for older women? Our findings fill a void in the current literature on gender labor income analysis by providing valuable insights to explain gender inequity among older workers.

Using annual household surveys from 2004 to 2019 (INEI, 2021a), we examine the existence of a gender labor income gap among older persons in Peru. We estimate two labor income models: Model 1 uses a basic set of demographics, socioeconomic, and personal characteristics as regressors (also called endowments); Model 2 uses the basic set plus additional personal characteristics. The Mincer-type relationship holds with positive returns for education and experience and the anticipated association to the endowments. The Oaxaca-Blinder decomposition yields an explained labor income gender gap of $44.4 \%$ (Model 1) and $51.5 \%$ (Model 2) for the mean difference of labor income between older male and female workers. It shows that after controlling for endowments approximately one half of the labor income difference remains unexplained and can be attributed to discrimination and labor segregation. In light of these results, we estimate Model 3 with two additional variables (head of household and beneficiary of intergenerational private transfer) which attempt to capture gendered stereotypes. With these two variables that provide information on gender discrimination, the explained labor income gap for Model 3 is $71.1 \%-$ an increase of $19.6 \%$. The unexplained component of the difference in labor income amounts to $28.8 \%$ that we attribute to unobserved variables that operate as post-labor market elements in patriarchal societies. It is very likely that the unexplained component could be further reduced if unobserved variables pertaining to 
gender discrimination could be incorporated. Results show that gender inequity during a woman's life-span manifests acutely among older women which raises important implications for policy interventions.

The article is organized as follows: In the next section, we briefly review Peru's rapid aging, which provides the context for our study. In Section 3, we present our data and main characteristics of the sample. Section 4 summarizes our estimation results. The last section concludes and provides some policy implications.

\section{Aging}

Peru is aging rapidly. In 2021, $13 \%$ of the national population (33 million) was $60+$. This proportion will increase to 30\% in 2070 (INEI, 2019; UN, 2019). Over the same period, people $80+$ will see their population share grow from $2 \%$ to $8.6 \%$. Fertility rates continue to drop (below 2), life expectancy at birth is 77 for both sexes, and no changes in migration patterns are anticipated (such as the recent 2017-2019 migrant surge from Venezuela where more than 800 thousand Venezuelans immigrated to Peru; INEI, 2019, Tables 4 and 10). The demographic dividend in Peru-where the total dependency ratio is at least $67,7 \%$, resulting in three working age persons supporting two children/older persons-will end by 2045. This data provides policy makers and society a two-decade period to enhance the national social protection system and ensure the well-being of older persons (INEI, 2020, p. 13; UN, 2019).

Covid-19 has impacted the demographic situation. Peru recorded one of the highest fatality rates globally: a total of 193 thousand dead from Covid-19 by mid-July 2021, which exceeded the average annual national deaths of 172 thousand in 2015-2020 (INEI, 2019, Table 13; Ministerio de Salud, 2021). Table 1 shows the distribution of deaths of older persons by gender. The fatality rate was much higher among older persons: $69.6 \%$ of all deaths were persons $60+$ and $43.8 \%$ were persons $70+$. Thirty five percent of all deaths were accounted for in the department of Lima, the capital, which concentrates one third of the total national population. The number of casualties was highest among males. There are at least two takeaways from this evidence. First, the demographic growth rate will drop further from its estimated $0.92 \%$ in $2020-2025$, and second, the gap in life expectancy at 60 for females vs. males will increase (UN, 2019). It should be noted that life expectancy for women at 60 years of age was 24.4 years and for men, 21.3. The age gap had been narrowing in recent years (UN, 2019).

The aging process advances, but coverage of both contributory and non-contributory pensions challenges the income security of older persons (Altamirano et al., 2019; Bernal et al., 2008; Casalí \& Pena, 2012; Cruz Saco, 1998; Cruz Saco \& Gil, 2021; Cruz Saco et al., 2018a, 2018b; Mesa-Lago, 2016, 2021; OECD, 2019; OECD et al., 2014). As 50\% of Peruvian older persons pack up every day and go to work, mostly as self-employed workers, they do so with considerable risk and often with underlying health issues that may affect their functionality and well-being. In 2021, more than $80 \%$ of male older persons had at least one chronic disease (e.g., arthritis, hypertension, heart and respiratory diseases, or diabetes) and $41 \%$ had at least one disability (e.g., mobility issues, difficulty seeing, or problems with understanding, communicating, or listening). These numbers were $70 \%$ and $49 \%$ for older women respectively (INEI, 2021b, Figure 9 and Table 6.2). During the pandemic, things did not get better. Not only were older persons more vulnerable when they contracted the virus, they were apprehensive about the loss of jobs and the prospect of increased poverty.

\section{Data and Main Characteristics of the Sample}

We use annual household surveys that are nationally representative and provide information on demographics (e.g., age, gender, marital status, household size, place of residence) and socioeconomic variables (e.g., educational attainment, employment status, labor income) among other characteristics from 2004 to 2019. We pool the data, restricting the sample to working older persons $60+$ who earn a labor income. The size of our pooled sample is 109,257 , after eliminating missing information. Working older persons $60+$ represent $50.3 \%$ of the total sample of persons $60+(217,471$ individuals). The other 108,214 individuals, if they receive any income at all, may earn one or more pension benefits (e.g., retirement, widower, disability, divorce), earn rents derived from assets, benefit from intergenerational transfers, and/or co-reside in family arrangements that provide

Table 1. Distribution of Covid-19 deaths by age and gender (July 2021).

\begin{tabular}{lllll}
\hline & $60+$ & Total deaths (\%) & $70+$ & Total deaths (\%) \\
\hline Both sex & 134,486 & 69,6 & 84,663 & 43,8 \\
$\%$ & 100,0 & & 100,0 & \\
Female & 50,719 & 26,2 & 32,651 & 16,9 \\
$\%$ & 37,7 & & 38,6 & \\
Male & 83,766 & 43,4 & 52,011 & 26,9 \\
$\%$ & 62,3 & & 61,4 & \\
\hline
\end{tabular}

Source: Ministerio de Salud (2021), authors' calculations. 
them with support. Also excluded from the pooled sample are 25,390 "unremunerated" older workers who do not have a listed income (a household survey category). To nobody's surprise, $81.9 \%$ of the unremunerated workers are women, $94.3 \%$ do not earn a contributory pension, $84,1 \%$ do not earn $P 65,96.5 \%$ are not affiliated to a pension scheme (those under the retirement age of 65), $82.6 \%$ are in a relationship (married or living with a partner), and $73.1 \%$ reside in rural areas. Basically, unremunerated workers are rural vulnerable women who live without a pension. For half of them, their mother tongue is Quechua, Aymara, or another native language.

Table 2 summarizes the basic characteristics of individuals (by gender and total) at the beginning, end, and in the pooled sample over the period of analysis. The sample size is 3,777 in 2004, 10,435 in 2019, and the pooled sample is 109,257 from 2004 to 2019 . The average age is 68 years. The gender composition oscillates around $40 \%$ female ( $60 \%$ male). The majority of older workers in the pooled sample are self-employed (81\%), with a higher proportion of female as self-employed. For the overall Peruvian labor force, the gender balance with respect to dependent and self-employed is more even.
Information on the annual labor income, in constant soles of $2019(\mathrm{~S} /)$, is presented by three quartiles or social classes (P25, P50, and P75) and by the 99th percentile class. Note that US\$1 is approximately $\mathrm{S} / 4$. In 2004, females in quartile 1 (P25), the poorest bottom $25 \%$ of the population, made $\mathrm{S} / 335$ or US\$83.75 annually (US\$7 per month). Males in the same quartile 1 made approximately twice as much, US\$178 annually (US\$14.8 per month). These values increased markedly over the fifteen-year period. Females' income increased by $268 \%$ (a $9.6 \%$ annual increase) and males' income by $314 \%$ (a 10.5\% annual increase). Similar strong increases in annual labor income were realized by quartiles 2 and 3 which showed the monetary income progress during a time of high economic growth accompanied by a drop in the national average poverty rate from $50 \%$ to $20 \%$. The strongest increase was experienced by females in the 99th percentile compared to a more modest gain for males in the same class. Women in the 99th percentile however began with much lower labor income.

Income data show severe skewness between social classes. In 2019, for example, the top 99th percentile females made US\$1,383 per month while women in

Table 2. Summary of main descriptive statistics 2004, 2019 and pooled sample from 2004 to 2019.

\begin{tabular}{|c|c|c|c|c|c|c|c|c|c|}
\hline \multirow[b]{2}{*}{ Main indicators } & \multicolumn{3}{|c|}{2004} & \multicolumn{3}{|c|}{2019} & \multicolumn{3}{|c|}{ Pooled sample 2004-2019 } \\
\hline & Female & Male & Total & Female & Male & Total & Female & Male & Total \\
\hline Sample, N & 1,226 & 2,551 & 3,777 & 4,113 & 6,322 & 10,435 & 40,009 & 69,248 & 109,257 \\
\hline Mean age & 68.4 & 68.2 & 68.3 & 68.3 & 68.4 & 68.4 & 68.5 & 68.3 & 68.4 \\
\hline \multicolumn{10}{|l|}{ Employment by status } \\
\hline Employees & 125 & 378 & 503 & 754 & 1,543 & 2,297 & 5,674 & 14,767 & 20,441 \\
\hline Self-employed & 1,101 & 2,173 & 3,274 & 3,359 & 4,779 & 8,138 & 34,335 & 54,481 & 88,816 \\
\hline \multicolumn{10}{|c|}{ Annual labor income (S/2019) } \\
\hline Quartile 1 (P25) & 335 & 712 & 531 & 1,231 & 2,199 & 1,614 & 617 & 1,280 & 950 \\
\hline Quartile 2 (P50) & 895 & 2,039 & 1,500 & 3,227 & 6,420 & 4,942 & 1,807 & 3,927 & 2,947 \\
\hline Quartile 3 (P75) & 2,134 & 4,885 & 3,854 & 7,910 & 14,521 & 12,121 & 4,827 & 10,341 & 8,257 \\
\hline P99 & 13,624 & 49,608 & 37,346 & 66,362 & 92,734 & 85,381 & 48,380 & 90,811 & 74,877 \\
\hline \multicolumn{10}{|l|}{ Contributory pensions } \\
\hline Yes & 34 & 278 & 312 & 152 & 601 & 753 & 1,519 & 7,474 & 8,993 \\
\hline No & 1,192 & 2,273 & 3,465 & 3,961 & 5,721 & 9,682 & 38,490 & 61,774 & 100,264 \\
\hline \multicolumn{10}{|l|}{ Type of pension system } \\
\hline$P P S$ & 9 & 46 & 55 & 264 & 891 & 1,155 & 1,464 & 6,683 & 8,147 \\
\hline NPS & 46 & 228 & 274 & 574 & 1,261 & 1,835 & 4,858 & 14,787 & 19,645 \\
\hline \multicolumn{10}{|l|}{ Education } \\
\hline Low (0-8 yrs.) & 1,113 & 2,084 & 3,197 & 2,830 & 3,701 & 6,531 & 31,582 & 46,778 & 78,360 \\
\hline Medium (9-13 yrs.) & 75 & 319 & 394 & 791 & 1,651 & 2,442 & 5,198 & 14,390 & 19,588 \\
\hline High (14+ yrs.) & 38 & 148 & 186 & 492 & 970 & 1,462 & 3,228 & 8,074 & 11,302 \\
\hline \multicolumn{10}{|l|}{ Location } \\
\hline Rural & 628 & 1,525 & 2,153 & 1,678 & 3,103 & 4,781 & 18,339 & 36,279 & 54,618 \\
\hline Urban & 598 & 1,026 & 1,624 & 2,435 & 3,219 & 5,654 & 21,670 & 32,969 & 54,639 \\
\hline
\end{tabular}

Notes: Sample, $\mathrm{N}=$ number of respondents in the survey; P25 is percentile 25th or quartile 1, P50 is percentile 50th or quartile 2, P75 is percentile 75th or quartile 3, P99 is the 99th percentile in the income distribution; seven respondents did not answer the question about education. Source: INEI (2021a), authors' calculations. 
quartile 1 made US\$26. Similarly, the top 99th percentile males made US\$1,932, and men in quartile 1 , US\$46. Two observations merit emphasis. First, the income distribution by social class reveals a strong stratification among older workers, analogous to the national pattern of severe inequality (Alarco et al., 2019; Cruz Saco et al., 2018; Desco, 2021; Mendoza et al., 2015). Second, the labor income distribution of older workers by gender shows severe inequality against women.

Table 3 presents the gender gap using the annual labor income for females as a proportion of annual male labor income for the respective quartiles and for the 99th percentile.

The gender income gap decreased by around $10 \%$ in the fifteen-year period for the first three quartiles, and it decreased notably for the 99th percentile. In this social class, females made a strong comeback (from $27.5 \%$ to $71.6 \%)$. For the pooled sample, females earned half the labor income of their male counterparts.

The large majority of working older persons do not earn a contributory pension (see Table 1). For the pooled sample, $92 \%$ have no contributory pension, and the proportion is higher for females, $96 \%$. This finding, while selfevident to some, proves the point: almost every older person who works does not have a contributory pension. In contrast, when looking at the total population of 60+, INEI (2021b, p. 10) indicates that one third earns a contributory pension, $24.9 \%$ from the NPS and $8.7 \%$ from the PPS. In all likelihood, individuals in the pooled sample work due to low pension coverage and inadequacy of the pension scheme.

Since the official retirement age is 65 years, one quarter of older workers are younger than the retirement age (65) and contribute to a pension scheme. Proportionally, more males than females report contributing to a pension scheme, and the number of people contributing has increased over the years. Of the older persons who contribute to a pension system, they are more than twice as likely to be affiliated with the NPS than the PPS.

The level of educational attainment has been improving over time. In $2004,84.6 \%$ had low level of educational attainment (0-8 years), $10.4 \%$ had middle school and high school education (9-13 years), and $4.9 \%$ had higher education (14+ years). Fifteen years later, in 2019, 62.5\% had low level of educational attainment, $23.2 \%$ had middle school and high school education, and $14.0 \%$ had higher education. However, INEI (2021b, p. 5) reports that for the general population of all persons $60+$ (i.e., working and not working), the educational attainment was higher in 2020: $52.4 \%$ had low education, $28,3 \%$ had medium education, and $19.3 \%$ had high education. These proportions are worse for older females. Overall, estimates show that older workers had fewer opportunities to advance their education.

Finally, respondents were well balanced in terms of their geographic residence (urban or rural).

\section{Estimation Results}

We use a Mincer-type semilog income regression where the dependent variable is the natural log of labor income (expressed in constant 2019 soles). The income variable in the analysis is from both the main and secondary occupations. Regressors (endowments) are age, region (eight different geographic locations), employment status (dependent or self-employed), education (measured in twelve levels), work experience (number of years at the job), having a contributory pension (PPS or NPS) or a social pension (P65), having another pension (widower, divorce, disability, other), affiliation to a pension scheme (for persons who are younger than 65), language (native, Spanish, foreign), marital status, number of household members, health insurance, and chronic disease. Following the Mincer-type relationship, we expect that labor income, the dependent variable, will be positively associated with level of educational attainment and experience. The other regressors complete the modeling of the dependent variable. We use a pooled OLS estimation with fixed effects and test for absence of multicollinearity and robustness. OLS estimations are conducted for three models: Model 1 uses a basic number of controls (age, region, employment status, education, having a pension, affiliation to a pension scheme, mother tongue, and region); Model 2 uses the basic number of regressors of the previous model plus additional controls (work experience, social pension [P65], having other pensions, marital status, number of household members, health insurance, and chronic disease); Model 3 adds two control variables: head of household and beneficiary of intergenerational private transfers. The justification for inclusion of these variables is as follows. First, in traditional, patriarchal societies, with strong machista values and familism (social structure that implies subordination of the individual to family relationships), the male figure as head of household is dominant. Hence, the number of male headed households tends to be higher in

Table 3. Female annual labor income as a proportion of male annual labor income, in \%.

\begin{tabular}{lccc}
\hline Income group & 2004 & 2019 & Pooled sample 2004-2019 \\
\hline Quartile 1 (P25) & 47.0 & 56.0 & 48.2 \\
Quartile 2 (P50) & 43.9 & 50.3 & 46.0 \\
Quartile 3 (P75) & 43.7 & 54.5 & 46.7 \\
P99 & 27.5 & 71.6 & 53.3 \\
\hline
\end{tabular}

Source: INEI (2021a), authors' calculations. 
communities with strong gendered stereotypes. Second, reciprocity relationships within kin and intergenerational solidarity are social norms that prompt younger generations to transfer money or in-kind resources to their elders, especially to moms and older women (Cruz Saco \& Zelenev, 2010; Pelaez \& Martinez, 2002; Ramos Padilla et al., 2009).

In Models 1 to 3, the estimated coefficients on the regressors (dummies and numerical variables) are statistically significant (at least at $p<.1$ but mostly at the $p<.001$ significance level) and have the expected signs. The coefficients on age show lower returns to aging. Returns on self-employment are positive relative to dependent employment. Earning a contributory pension, being affiliated to a pension scheme, having health care insurance, living with other household members each impact labor income positively, but residing in less urbanized regions is negatively associated to the regressed variable. Schooling and experience (measured by years at the job) have the anticipated positive impact on income earnings with the highest coefficients at grade 4 in primary school and technical certification. Speaking a native language mother tongue (e.g., Aymara, Quechua, other) relative to Spanish decreases labor income but having a foreign mother tongue (e.g., English, Portuguese) increases labor income. Earning the social pension, $\mathrm{P} 65$, is negatively associated to labor income, which was also a finding in Gertler and Galiani (2016) and Macroconsult and Instituto Cuánto (2016). Being a widower, divorced, or separated are negatively associated to labor income, but being a single person is positively associated to labor income. Earning other pensions (e.g., orphan, disability, widower) reduce the labor income. Finally, chronic disease was not a significant dummy.

Model 3 was designed to capture the outcome of post labor gender market discrimination-other than personal characteristics-represented by gendered stereotypes in family structures (a feature of patriarchal societies). The variable head of household is positively associated to labor income. And the variable beneficiary of intergenerational private transfers - an alternative source of income for older women-is negatively associated to labor earnings. This variable represents how nuclear and extended family members compensate older women, in particular, for their previous and current roles as family care-givers in support of their well-being.

We use the Oaxaca-Blinder decomposition for the pooled sample to examine the mean labor income difference (D) between the group of older male workers and older female workers respectively (Ariza \& Montes-Rojas, 2019; Duncan \& Sandy, 2013; Fortin et al., 2011; Jann, 2008; Ñopo, 2008). Following the order of presentation of how D is accounted for in Sharma (2017), we identify three components:

1. The endowment effect $(E)$ : It is the part of the income difference that is due to group difference in the regressors. Our findings suggest, therefore, that older males and older females have different endowments (i.e., personal characteristics) that support their labor income.

2. The coefficient effect $(C)$ : This component is the contribution of differences in the coefficients of regressors. In other words, this is the part of the gender income gap which arises because older persons' endowments do not impact labor income in a gender-neutral way. It is possible to justify this gender gap as one motivated by two explanations. First, the gap might be explained due to a gendered deviation in older persons' endowments from the gender-neutral benchmark (e.g., a man's experience has more value than a woman's). Second, another gap arises due to the fact that older women's responses in the labor market are not gender neutral (i.e., discrimination; e.g., the market values a man's experience more than it values a woman's experience).

3. The interaction component (I): This component refers to the simultaneous interaction of the previous two effects. A positive interaction term adds to the coefficient effect $C$ of the gender gap, and a negative interaction reduces said effect.

Oaxaca-Blinder results for the pooled sample and Models 1 to 3 -as well as for the three components, E, $C$, and I as described above-are presented in Table 4. These estimations are robust, do not exhibit multicollinearity, and the R-squared are 0.4232 for Model 1, 0.4426 for Model 2, and 0.4429 for Model 3. The difference $R$ is 0.561 for the three models. The part of $R$ that is due to the endowment effect (also called the "explained component") is 0.249 in Model 1 , increases to 0.289 in Model 2, and further increases to 0.399 in Model 3. The coefficient effect (also called the "unexplained component") decreases from 0.284 , to 0.239 and 0.209 in Models 1, 2, and 3, respectively. The interaction effect is positive in Models 1 and 2 but negative in Model 3. Here, the interaction effect reduces the unexplained component or discrimination precisely because two variables were introduced to capture the gendered social norms that permeate work and social relationships that ultimately affect the gender income gap.

These results can also be presented as percents. Model 1 and Model 2 explain $44.4 \%$ and $51.5 \%$ of the gender labor income gap respectively. Model 3 , with the introduction of variables which capture gender discrimination, increases the explained component to $71.1 \%$ and the discrimination or unexplained component accounts for $28.8 \%$ of the gap.

\section{Conclusions and Policy Implications}

We used the Peruvian household surveys from 2004 to 2019 to assess the existence of a gender income gap among older workers $(60+)$. Descriptive statistics show that, on average, women's labor income is half 
Table 4. Oaxaca-Blinder decomposition results using male vs female mean labor income, 2004-2019.

\begin{tabular}{|c|c|c|c|}
\hline & Model 1 & Model 2 & Model 3 \\
\hline Difference (R) & $0.561 * * *$ & $0.5 r 61 * * *$ & $0.561 * * *$ \\
\hline Due to endowment (E) & $0.249 * * *$ & $0.289 * * *$ & $0.399 * * *$ \\
\hline Due to coefficient (C) & $0.284 * * *$ & $0.239 * * *$ & $0.209 * * *$ \\
\hline Due to Interaction (I) & $0.0281 * * *$ & $0.0324 * *$ & $-0.0474 *$ \\
\hline $\begin{array}{l}\text { Explained component, } \\
\text { Endowment as percent of total }(E / R)\end{array}$ & 44.39 & 51.52 & 71.12 \\
\hline $\begin{array}{l}\text { Unexplained component, } \\
\text { Discrimination as percent of total }(C+I / R)\end{array}$ & 55.63 & 48.38 & 28.81 \\
\hline
\end{tabular}

Note: Significance levels are $p<.1,{ }^{*} p<.05,{ }^{* *} p<.01, * * * p<.001$. Source: INEI (2021a), authors' calculations.

the income of their male counterparts (see Table 3 ). The Oaxaca-Blinder results confirm the existence of a gender labor income gap where differences in endowments explain between $44.4 \%$ and $51.2 \%$ of the income gap when regressors pertain to personal characteristics (see Table 4). We then incorporate two variables that proxy gendered stereotypes present in patriarchal societies (head of household and beneficiary of intergenerational private transfers). With these two additional variables that provide information on gendered attitudes, we increase the explained component from $51.2 \%$ to $71.1 \%$, a substantial increase. The unexplained component of the difference in labor income amounts to $28.8 \%$ that we attribute to unobserved variables that operate as post-labor market elements in patriarchal societies. Notwithstanding better educational attainment of younger women, several scholars have documented high levels of discrimination at home and at the workplace that are resilient. At home, in particular for this age group, women are assumed to do the chores, to care for children, the elderly, and family members who are sick. Sustaining the family in this way is a social norm that has been passed on from generation to generation. Thus, for older women, gender inequity has cumulated over time.

This article was motivated by three critical issues: Are the same institutional patterns and value systems that have perpetuated women discrimination in the labor force playing out with similar intensity during old age? If so, how? What lessons can we draw to inform policy interventions to eliminate gender inequity for all ages but more specifically for older women? The answer to the first posed question is affirmative. The same institutional patterns and value systems that have perpetuated women discrimination in the labor force continue to play out with similar intensity during old age. The answer to the second question is that gender inequity and discrimination manifests in a variety of ways. First, women earn lower income than those determined by their endowment, differences in coefficients regarding their endowments for a gender-neutral threshold, and interaction of the latter with the differences in endowments. Second, women are distributed in social classes that show severe inequality among the same gender group (same is true for men). Women at the P99th earn significantly higher income than poor women who, on average, live in rural areas and are less educated. It means that the labor income distribution among women requires an intersectional approach. The latter means that women's identities and livelihoods are not only determined by their common gender but also by socio-economic class, ethnicity, being old or being very old, their urban or rural background and other dimensions that explain the diversity of their experiences. These dimensions need to be taken into account for the design of best interventions. Third, older women and men probably work because the pension coverage is insufficient and their financial and self-assurance needs are vast.

And finally, with regard to the third question, active interventions such as those recommended by BarrantesCáceres and Matus-Trifu (2019), Beltrán et al. (2021), Gálvez (2001), Lavado (2017), and Mesa-Lago et al. (2021) need to be instituted to undo historical and institutional social norms that maintain gender inequity. In particular, regarding older women, governments should increase non-contributory pensions and establish universal benefits that are equivalent to a living wage. Women in rural areas and unremunerated older workers should be prioritized. Governments should adopt compensation mechanisms for moms and for women who stop contributing to give birth and/or take on care-giving at home. More importantly, an inclusive social protection system in support of older females should also include effective health care services, adequate housing, and the provision of care at home or in nursing homes that should be funded with general government revenues and with social security contributions that should be mandatory.

In 2020, Peru ratified the Inter-American Convention on Protecting the Human Rights of Older Persons, an instrument adopted by the Organization of American States in 2015 which specifically protects the rights of the elderly (Rodriíguez-Pinzón, 2016). Unfortunately, ten countries must ratify the Convention before its terms go into effect. Including Peru, only nine countries have done so. One of the important contributions of the Convention is its intersectional approach to gender. The Convention explicitly references the importance of 
a gender perspective (as well as gender equality) when designing policies and programs. Including a gender perspective is important in the context of old age rightsprotection, because in many places-including Latin America-the burdens of old age are not shared equally. Zapy (2018) argues that the production and distribution of care in most Latin American societies concentrates within families. Since generations of women have been providing this care, a comprehensive revamping of the organization of care-for children and older persons in particular-is a necessary condition to empower women economically and in society. Uruguay stands out in this respect. In 2015, the government of Uruguay adopted a multi-prone national integrated care system (NICS) that considers care as a basic right for all people through public policy interventions. NICS shifts caring responsibilities to the government, the private sector, and non-governmental organizations, thereby progressively relieving women from caregiving that impaired their labor participation and upward mobility (Salvador, 2019).

One way in which countries can overcome gender exclusionary social protection policies is to reconceptualize social insurance as a system which promotes social investment rather than one which is based on mandatory salary contributions. Contributory schemes often have significant coverage gaps which reflect and intensify long-lasting inequalities from the labor market. On the other hand, social investment interventions in vulnerable groups (children, youth, low-skilled workers, women, older persons, and persons with disabilities) can aim at the inclusion of those with the most need who have traditionally been marginalized (Amarante et al., 2019). In Peru, while the adoption of an integrated care system like the NICS must await more favorable political and financial conditions, other specific policy recommendations are in order. For example, as documented by Amarante et al. (2016) - with respect to Argentina, Brazil, Chile, and Uruguay - and by Arza (2017) - with respect to Europe-minimum pensions and social pensions are interventions that can reduce the gender pension gap (though given the very low contributory rates of female workers in Peru, the preferable intervention in the near future is a more robust social pension). Beyond minimum and social pensions, a set of additional recommendations emanate from the OECD (2016) analysis on gender equality in the Pacific Alliance (Chile, Colombia, Mexico, and Peru). To reverse the structural drivers of gender inequality, the OECD (2016) proposes the following actions: (a) ensure the enrollment of girls in fields of study with high returns to education (STEM fields); (b) help women transition into higher education and provide child support if they are moms; (c) expand employment to formal jobs with social security protection; (d) enhance access to finance and technical assistance to female entrepreneurs; (e) reconcile and balance work at home and in the work place; (f) raise awareness of violence against women (home, work, public spaces), reduce gender biases in the justice and police systems, and help women access justice; (g) eliminate gender wage discrimination, adopt flexible working hours for women, and promote the recruitment, training and promotion of women; and (h) continuous assessment of programs to attain gender equity.

\section{Acknowledgments}

The authors thank the comments of anonymous reviewers.

\section{Conflict of Interests}

The authors declare no conflict of interests.

\section{References}

Alarco, G., Castillo, C., \& Leiva, F. (2019). Riqueza y desigualdad en el Perú: Una visión panorámica [Wealth and inequality in Peru: A panoramic vision]. Oxfam. https://cng-cdn.oxfam.org/peru.oxfam.org/ s3fs-public/file_attachments/Riqueza-ydesigualdad-en-el-Peru-vision-panoramica.pdf

Altamirano, A., Berstein, S., Bosch, M., Caballero, G., García-Huitrón, M., Keller, L., \& Silva-Porto, M. T. (2019). Diagnóstico del sistema de pensiones peruano y avenidas de reforma [Analysis of the Peruvian pension system and reform proposals]. InterAmerican Development Bank. https://publications. iadb.org/publications/spanish/document/Diagn\%C3 \%B3stico_del_sistema_de_pensiones_peruano_y_ avenidas_de_reforma_es.pdf

Amarante, V., Colacce, M., \& Manzi, P. (2016). La brecha de género en jubilaciones y pensiones. Los casos de Argentina, Brasil, Chile y Uruguay [The gender gap in contributory and social pensions. The cases of Argentina, Brazil, Chile and Uruguay]. United Nations; ECLAC; Cooperación Española. https://repositorio. cepal.org/handle/11362/40650?locale-attribute=en

Amarante, V., Colacce, M., \& Tenenbaum, V. (2019). The national care system in Uruguay: Who benefits and who pays? Population and Development Review, 45, 97-122. https://doi.org/10.1111/padr.12271

Ariza, J., \& Montes-Rojas, G. (2019). Decomposition methods for analyzing inequality changes in Latin America 2002-2014. Empirical Economics, 57(6), 2043-2078. https://doi.org/http://dx.doi.org/ 10.1007/s00181-018-1518-4

Arza, C. (2017). El diseño de los sistemas de pensiones y la igualdad de género ¿Qué dice la experiencia europea? [The design of pension systems and gender equality. What are the lessons from the European experience?]. United Nations; ECLAC; Cooperación Española. https://repositorio.cepal.org/handle/ 11362/40936

Barrantes-Cáceres, R., \& Matos-Trifu, P. (2019). "En capilla": Desigualdades en la inserción laboral de mujeres jóvenes ["In the chapel": Inequality in the 
labor participation of young women]. Instituto de Estudios Peruanos. http://repositorio.iep.org.pe/ bitstream/handle/IEP/1162/Barrantes-Roxana_ Matos-Paulo_Desigualdades-insercion-laboralmujeres-jovenes. pdf?sequence $=1 \&$ isAllowed $=y$

Beltrán, A., \& Lavado, P. (2014). El impacto del uso del tiempo de las mujeres en el Perú: Un recurso escaso y poco valorado en la economía nacional [The impact of Peruvian women's use of time: A scarce and poorly valued resource in the domestic economy]. CISEPA (PUCP), Universidad del Pacífico. https://repositorio. up.edu.pe/bitstream/handle/11354/967/DD1409+ El+impacto+del+uso+del+tiempo+de+las+mujeres+ en+el+Per\%C3\%BA+un+recurso+escaso+y+poco+ valorado+en+la+econom\%C3\%ADa+nacional+2.pdf? sequence $=1$

Beltrán, A., Cruz Saco, M. A., \& Pérez, L. (2021). Hacia la equidad económica de género entre las adultas peruanas [Toward gender economic equity among female adults]. In A. Beltrán, C. A. Sanborn, G. Yamada, \& Eds. (Eds.), En búsqueda de un desarrollo integral: 20 ensayos en torno al Perú del Bicentenario [Searching for a comprehensive development process: 20 essays on Peru at its bicentennial celebration] (pp. 441-482). Fondo Editorial de la Universidad del Pacífico. https://fondoeditorial.up.edu.pe/producto/enbusqueda-de-un-desarrollo-integral-20-ensayosen-torno-al-peru-del-bicentenario-libro-digital

Bernal, N., Muñoz, A., Perea, H., Tejada, J., \& Tuesta, D. (2008). A look at the Peruvian pension system: Diagnosis and proposals. BBVA. https://www.bbvare search.com/wp-content/uploads/migrados/Alookat theperuvianpensionsystem_tcm348-189767.pdf

Casalí, P., \& Pena, H. (2012). Los trabajadores independientes y la seguridad social en el Perú [Selfemployed workers and social security in Peru]. International Labour Organization. https://www.ilo.org/ global/docs/WCMS_339151/lang-V-es/index.htm

Center for Financial Inclusion, \& HelpAge International. (2015). Aging and financial inclusion: An opportunity. Center for Financial Inclusion. https:// www.centerforfinancialinclusion.org/aging-andfinancial-inclusion

Cruz Saco, M. A. (1998). The pension reform in Peru. In M. A. Cruz-Saco \& C. Mesa-Lago (Eds.), Do options exist? The reform of pension and health care systems in Latin America (pp. 165-185). University of Pittsburgh Press.

Cruz Saco, M. A., \& Gil, M. (2021). The pension system in Peru: Parallels and intersections. International Journal of Social Welfare, 30(3), 316-329. https://doi. org/10.1111/ijsw.12467

Cruz Saco, M. A., Seminario, B., \& Campos, C. (2018). Desigualdad (re)considerada: Perú 1997-2015 [Inequality (re)considered: Peru 1997-2015]. Journal of Economics, Finance and International Business, 2(1), 12-52. http://dx.doi.org/10.20511/jefib.2018. v2n1.219
Cruz Saco, M. A., Seminaro, B., Leiva, F., Moreno, C., \& Zegarra, M. A. (2018a). La desestructuración del sistema peruano de pensiones [The destructuring of the Peruvian pension system]. Fondo Editorial de la Universidad del Pacífico. http://hdl.handle.net/11354/ 2098

Cruz Saco, M. A., Seminario, B., Leiva, F., Moreno, C., \& Zegarra, M. A. (2018b). El porvenir de la vejez en el Perú. Demographia, empleo y ahorro [The future of old age in Peru. Demographics, labor and savings]. Fondo Editorial de la Universidad del Pacífico.

Cruz Saco, M. A., \& Zelenev, S. (Eds.). (2010). Intergenerational solidarity. Strengthening economic and social ties. Palgrave McMillan. https://doi.org/ $10.1057 / 9780230115484$

Desco. (2021). Perú hoy. Más desiguales que nunca [Peru today. More unequal than ever]. https://www.desco.org.pe/mas-desiguales-quenunca-serie-peru-hoy- $\mathrm{n}^{\circ}$-38-marzo-2021

Duncan, K., \& Sandy, J. (2013). Using the BlinderOaxaca decomposition method to measure racial bias in achievement tests. Review of Black Political Economy, 40(2), 185-206. https://doi.org/10.1007/ s12114-012-9146-2

Fortin, N., Lemieux, T., \& Firpo, S. (2011). Decomposition methods in economics. Handbook of Labor Economics, 4(A), 1-102. https://doi.org/10.1016/S01697218(11)00407-2

Gálvez, T. (2001). Aspectos económicos de la equidad de género [Economic aspects of gender equity]. ECLAC. https://repositorio.cepal.org/bitstream/handle/ 11362/5882/1/S01060530_es.pdf

Gertler, P., \& Galiani, S. (2016). Evaluación de impacto del programa Pensión 65: Nueva evidencia causal de las pensiones no contributivas en Perú [Impact assessment of the Pension 65 program: New causal evidence of non-contributory pensions in Peru]. Innovations for Poverty Action. https://www.pension65. gob.pe/wp-content/uploads/Evaluacion-deImpacto-Pension-65.pdf

Huenchuan, S. (2013). Envejecimiento, solidaridad y protección social en América Latina y el Caribe. La hora de avanzar hacia la igualdad [Aging, solidarity and social protection in Latin America and the Caribbean. Time to make progress toward equality]. ECLAC; United Nations. https://www.cepal.org/es/ publicaciones/2617-envejecimiento-solidaridadproteccion-social-america-latina-caribe-la-hora

Huenchuan, S. (Ed.). (2012). Los derechos de las personas mayores en el siglo XXI: Situación, experiencias $y$ desafios [The rights of older persons in the 21th century: Situation, experiences and challenges]. ECLAC; United Nations. https://repositorio. cepal.org/handle/11362/1465?locale-attribute=en

International Labour Organization. (2003). International training compendium on labour statistics. https://www.ilo.org/public/english/bureau/stat/ download/module.pdf 
Instituto Nacional de Estadística e Informática. (2019). Perú: Estimaciones y proyecciones de la población nacional, 1950-2070 [Peru: Estimates and projections of the national population, 1950-2070]. https://www.inei.gob.pe/media/MenuRecursivo/ publicaciones_digitales/Est/Lib1665/index.html

Instituto Nacional de Estadística e Informática. (2020). Estado de la población peruana 2020 [Situation of the Peruvian population in 2020]. https://www.inei.gob.pe/media/MenuRecursivo/ publicaciones_digitales/Est/Lib1743/Libro.pdf

Instituto Nacional de Estadística e Informática. (2021a). National household surveys (several years). https:// www.inei.gob.pe/bases-de-datos/

Instituto Nacional de Estadística e Informática. (2021b). Situación de la población adulta mayor, EneroMarzo 2021. No 2-Junio 2021 [Situation of the population of older persons, January-March 2021. No 2-June 2021]. https://www.inei.gob.pe/media/ MenuRecursivo/boletines/02-informe-tecnicopoblacion-adulta-mayor-ene-feb-mar-2021.pdf

Jann, B. (2008). A Stata implementation of the BlinderOaxaca (Working Paper No. 5). ETH. https://core.ac. uk/download/pdf/6442665.pdf

Lavado, T. (2017). Penalizaciones salariales por maternidad: El costo de ser madre en el Perú [Salary reduction due to maternity. The cost of being a mom in Peru] (Final Report PBA2AN60-314). International Development Research Centre, Consorcio de Investigación Económica y Social. https://www.cies. org.pe/sites/default/files/investigaciones/ penalizaciones_salariales_por_maternidad_ el_costo_de_ser_madre_en_el_peru__tamia_lavado.pdf

Macroconsult, \& Instituto Cuánto. (2016). Elaboración del estudio de percepción de la calidad de los servicios de los programas sociales del MIDIS [Study on the perception of service quality of MIDIS programs]. Ministerio de Economía y Finanzas. https://www.scribd.com/document/357041514/ Estudio-de-Percepcion-MACROCONSULT

Mendoza, W., López, S., Contreras, C., \& Mazzeo, C. (2015). La desigualdad de la distribución de ingresos en el Perú: Orígenes y dinámica económica y política [Inequality in Peru's income distribution: Causes, economic and political dynamics]. Fondo Editorial de la Pontificia Universidad Católica del Perú.

Mesa-Lago, C. (2016). Sugerencias para la re-reforma de pensiones en el Perú [Suggestions for the re-reform of pensions in Peru]. Apuntes, 43(78), 41-60. http:// hdl.handle.net/11354/1436

Mesa-Lago, C. (2021). Evaluation of four decades of pension privatization in Latin America, 1980-2020: Promises and reality. Friedrich Ebert Stiftung. https://papers.ssrn.com/sol3/papers.cfm?abstract_ id $=3812430$

Mesa-Lago, C., Cruz Saco, M. A., \& Gil, M. (2021). Pension coverage in Latin America: Trends and inequalities.
International Social Security Review, 74(2), 83-104. https://doi.org/10.1111/issr.12266

Ministerio de Salud. (2021). Dataset de fallecidos por Covid-19 [Database on COVID-19 deaths] [Data set]. https://www.datosabiertos.gob.pe/dataset/ fallecidos-por-covid-19-ministerio-de-saludminsa/resource/4b7636f3-5f0c-4404-8526

Ministerio de Trabajo y Promoción del Empleo. (2019). Electronic payroll. https://www2.trabajo.gob.pe/ estadisticas/anuarios-estadisticos

Ñopo, H. (2008). An extension of the Blinder-Oaxaca decomposition to a continuum of comparison groups. Economics Letters, 100(2), 292-296. https://doi.org/ 10.1016/j.econlet.2008.02.011

OECD, IADB, \& World Bank. (2014). Pensions at a glance: Latin America and the Caribbean. http://dx.doi.org/ 10.1787/pension_glance-2014-en

OECD. (2016). Gender equality in the Pacific Alliance: Promoting women's economic empowerment. https:// doi.org/10.1787/9789264262959-en

OECD. (2019). OECD Reviews of pension systems: Peru. https://doi.org/10.1787/e80b4071-en

Olivera, J., \& Clausen, J. (2014). Las características del adulto mayor peruano y las políticas de protección social [Characteristics of the Peruvian older person and social protection policies]. Economía, 37(73), 75-112.

Pelaez, M., \& Martinez, I. (2002). Equity and systems of intergenerational transfers in Latin America and the Caribbean. Revista Panamericana de Salud Publica/Pan American Journal of Public Health, 11(5/6), 439-443. https://doi.org/10.1590/S102049892002000500021

Ramos Padilla, M. A., Vera-Tudela, D., \& Cárdenas, M. K. (2009). Las personas adultas mayores y su contribución a la lucha contra la pobreza [Older persons and their contribution to fighting poverty]. United Nations Population Fund; MIDIS.

Rodríguez-Pinzón, D. (2016). Inter-American convention on protecting the human rights of older persons. International Legal Materials, 55(5), 985-1006. Cambridge University Press.

Salvador, S. (2019). The national integrated care system in Uruguay. An opportunity for the economic empowerment of women. UN Women. https:// www2.unwomen.org/-/media/field\%20office\% 20americas/documentos/publicaciones/2019/10/ snic\%20web\%20ingles.pdf?la=en\&vs $=2843$

Sharma, S. (2017). Effect of endowments on gender wage differentials: A decomposition analysis for Indian labour market. Economic Affairs, 62(4), 609-620. https://doi.org/10.5958/0976-4666.2017.00074.2

Stark, A., Folbre, N., Shaw, L. B., Smeeding, T. M., Sandström, S., Shaw, L. B., Lee, S., \& Chung, K. (2005). Explorations gender and aging: Cross-national contrasts. Feminist Economics, 11(2), 163-197. https:// doi.org/10.1080/13545700500115985

UN. (2019). World population prospects 2019. https:// 
population.un.org/wpp/Download/Standard/

Population

Zapy, V. (2018). Las políticas de cuidado en Argentina. Avances y desafíos [Caregiving policies in Argentina.
Progress and challenges]. International Labour Organization. https://www.ilo.org/wcmsp5/groups/ public/---americas/---ro-lima/---ilo-buenos_aires/ documents/publication/wcms_635285.pdf

\section{About the Authors}

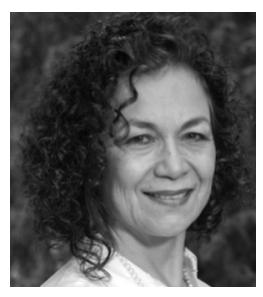

Maria Amparo Cruz Saco, Joanne Toor Cummings '50 professor of economics at Connecticut College (USA) and associated researcher at Universidad del Pacífico (Lima, Peru), earned a BS and licenciatura both in economics (Universidad del Pacífico). She is a graduate certificate in Latin American Studies, $\mathrm{MA}$ (economics) and PhD (economics) from the University of Pittsburgh. Her fields of expertise include ageing, macroeconomics, pensions, and social protection. She has authored five books, co-edited two volumes on social protection, and published articles in professional journals and book chapters. She serves on editorial boards, consultant for several organizations and official institutions, has held senior administrator positions at Peru's development bank COFIDE, Connecticut College, and Wesleyan University. She was a Fulbright scholar $(2007,2015)$, past recipient of the Lenore Tingle Chair in Economics at Connecticut College, past president of the New England Council on Latin American Studies, and chair of La Latina Network of the Hispanic Alliance of Southeastern Connecticut.

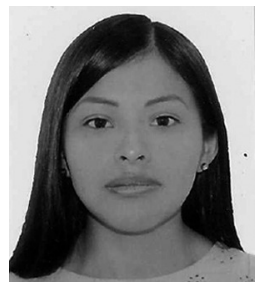

Miriam Gil, data and research analyst at the Peruvian Health Ministry, holds a BA in economics (Universidad Nacional Mayor de San Marcos). She served as a research assistant at the Research Center Universidad del Pacífico, where she collaborated on several research projects on old age, pension coverage, and productivity growth. She is author and co-author of several journal articles and book chapters, and the winner of the XX Annual Research Contest, Economic and Social Research Consortium (CIES, Canada).

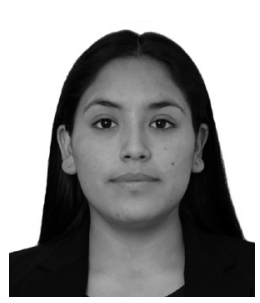

Cynthia Campos, an economics student at Universidad del Pacífico, has held research assistant positions, collaborated with various research projects, and co-authored two journal articles. For her graduation thesis she is estimating the patterns of income distribution among older persons in Peru. 